\title{
The Toxic Effects of Methotrexate on the Cerebellar Cortex of Adult Albino Rats and the Protective Role of Vitamin C: A Light Microscopic Study
}

\author{
DORREIA A.M. ZAGHIOUL, M.D.*; SALWA M. OUIES, M.D.**; WAIL M. GAD EL-RAB, M.D.*** and \\ AHLAM W. MOHAMED, M.Sc.**
}

The Department of Human Anatomy \& Embryology, Faculty of Medicine, Assuit University*, Sohag University** and Faculty of Medicine, Al-Azhar University, Assiut***

\begin{abstract}
Background: Cerebellum is the region of brain responsible for multiple motor and cognitive functions. It is formed of two cerebellar hemispheres separated by fissures. It is formed of lobes, lobules and folia; each folium is formed of cerebellar cortex and medulla. Methotrexate is anti-metabolic drug used in treatment of cancer, it has neurotoxic effect, and it produces oxidative stress in nervous tissue. Vitamin $\mathrm{C}$ is powerful antioxidant; it is a powerful free radical scavenger.
\end{abstract}

Aim of Study: The aim of this work is to study the toxic effects of methotrexate and the possible protective role of vitamin C.

Material and Methods: In this study, 30 rats are divided in to 3 groups (Group 1) received no treatment. (Group 2) received $10 \mathrm{mg} / \mathrm{kg}$ methotrexate injected intraperitoneal once time per week foe four weeks. (Group 3) received vitamin C $20 \mathrm{mg} / \mathrm{kg}$ by intragastric tube every other day for four weeks and methotrexate as same dos of group 2. At the end of experiment, rats are sacrificed and cerebella are taken and processed for light microscopic examination.

Results: There are histological changes in group treated with methotrexate (2) in the form of decreased thickness of granular layer. Purkinje cells shows shrinkage in cell bodies, decrease in number, lost mono laminar organization. Molecular layer showed decreased cellularity. After administration of vitamin $\mathrm{C}$, these cellular changes are decreased, molecular and granular cell layer thickness are restored.

Conclusion: Methotrexate is a toxic drug, it destroys the cerebellar cortex, but when administrated with vitamin C, its toxicity is decreased.

Key Words: Cerebellar cortex - Methotrexate - Vitamin C.

\section{Introduction}

CEREBELLUM is the region of the brain that is important for number of motor and cognitive functions [1]. It plays an important role in movement

Correspondence to: Dr. Dorreia A.M. Zaghloul, The Department of Human Anatomy \& Embryology, Faculty of Medicine, Assuit University and posture [2]; it is responsible for control of muscle tone and equilibrium [3]

It is involved in multiple cognitive functions: sensory discrimination, attention, planning learning and memory [4]. It is connected to limbic lobe, so it has a role in emotion [5]. It occupies posterior cranial fossa dorsal to pons and medulla oblongata from which separated by fourth ventricle [6] separated from cerebrum by dural fold called tentorium cercebelli [7]

It is formed two large cerebellar hemispheres separated by vermis. Outer surface contains multiple fissures and sulci which divided it in to multiple lobes, lobules and folia, beneath the cerebellar cortex, a white matter core celled medulla [8]

Cerebellar cortex is formed of 3 layers; outer molecular, intermediate Purkinje and inner granular cell layer [9]

Methotrexate is anti-metabolic drug used in treatment of neoplastic diseases, other multiple inflammatory and autoimmune diseases; it is antiproliferative and cytotoxic drug [10]. Methotrexate has a direct toxic effect on nervous system; it produces oxidative stress and release oxygen reactive species (ROS) [11]

$\mathrm{VC}$ is a water solublevitamin acting as an antioxidant thus preventing and ameliorating brain damage, it is the most important antioxidant in plasma [12]. It is the most important free radical scavenger [13].

In brain tissue, it is present in higher levels than other organs [14]. It is absorbed from diet and 
enters central nervous system through choroid plexus which is transported actively [15]. VC has been implicated in neuron development and functional maturation, also glial and neuronal differentiation [16].

\section{Material and Methods}

In this study,thirty adult albino rats their weight rang 200 to $250 \mathrm{gm}$, were bought from the animal house of Sohag Faculty of Science. They were reared under standard conditions of feeding, temperature at Sohag Faculty of Medicine, animal house. Ethical clearance for the use of animals was got from the Institutional Animal Ethics Committee prior to the beginning of the work.

\section{Animals were divided in to 3 groups:}

- Group 1: Control group received no treatment.

- Group 2: Received 10mg/kg methotrexate injected intaperitoneal once per week for four weeks [17]

- Group 3: Received 20mg/kg Vitamin C by intagastric tube each other day for four weeks [18] and received methotrexate like group 2 .

After end of the experiment, animals are selected randomly, anaesthized with ether and decapitated and skulls were opened, cerebellum was taken and cut to sagittal sections then fixed immediately in $10 \%$ formalin to obtain serial paraffin sections, according to [19]. Specimens are stained with (H\&E) staining then specimens are examined by light microscope. These steps were processed at Faculty of Medicine, Sohag University at 2019.

\section{Results}

Group-1 (Figs. 1,2): Cerebellum was formed of multiple folia; each folium was separated from other by narrow sulci. Each folium is formed of outer gray matter called cerebellar cortex and inner white matter called medulla. Cerebellar cortex shows 3 layers; outer molecular layer shows multiple fibers and small number of cells; superficial stellate cells and large deep basket cells. Purkinje cells appear large and arranged in one raw, it was flask shaped with pale basophilic cytoplasm vesicular nuclei with prominent nucleoli. Granular cells were densely packed cells with deeply stained nuclei, in between them, there are a small acidophilic area called (cerebellar glomerulus).

Group-2 (Figs. 3,4): Cerebellar layer shows marked thinning in layers especially granular cell layer with marked decreased cellularity in molecular cell layer. Molecular layer shows perineural spaces around basket cells which are smaller in size. Purkinje cells lost its mono laminar arrangement and its flask shape. Purkinje cells are irregular, shrunken with darkly stained homogenous cytoplasm and faint nuclei, multiple vacuolated areas in between them. Granule cells shows abnormal distribution, clumping and more identified cerebellar glomeruli.

Group-3 (Figs. 5,6): Cerebellar cortex layers shows more preserved thickness and molecular layer shows normal cellularity. Some Purkinje cells appear with normal size and shape and arrangement, but other cells appear with irregular and homogenous cytoplasm, vacuolated areas around it are less identified, Granular cell layer shows normally distributed cells with less identified cerebellar glomeruli, Molecular cell layer shows more cellularity, normally sized and more abundant basket cells,there are no perineural spaces around them.

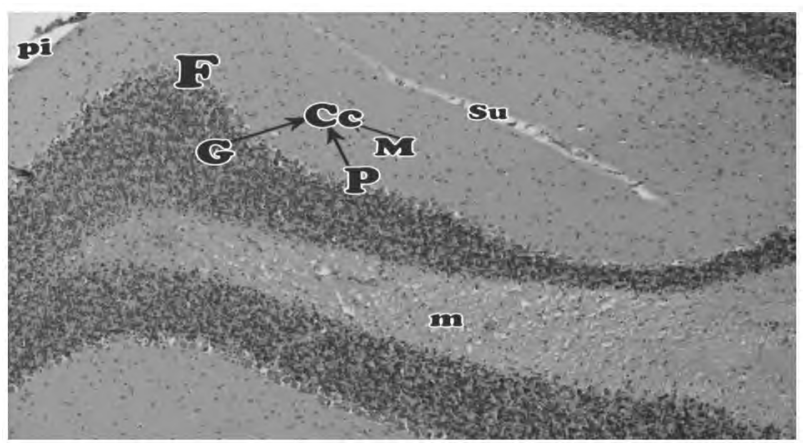

Fig. (1): A photomicrograph of a section in the rat cerebellar cortex of control group showing cerebellar folium (F). It is separated from another folium by narrow sulcus $(\mathrm{Su})$. It is composed of outer cover of grey matter called cerebellar cortex $(\mathrm{Cc})$ and inner white matter called medulla $(\mathrm{m})$, it is covered externally with pia matter (pi), $\mathrm{Cc}$ is formed of three layers; outer molecular (M), intermediate Purkinje (P) and inner granular cell layer (G) (H \& E x 100).

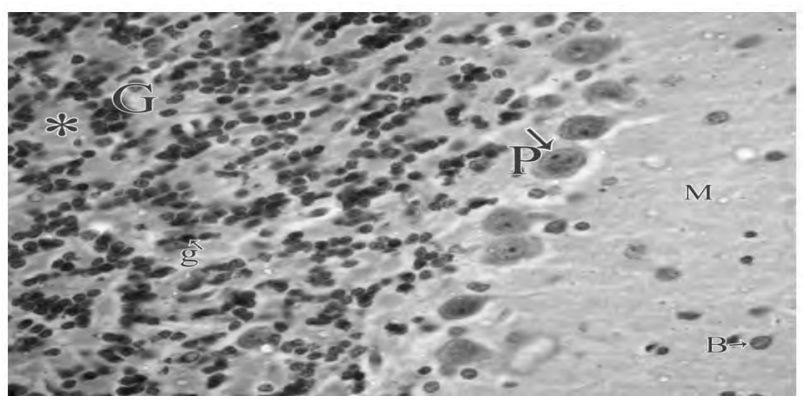

Fig. (2): A photomicrograph of a section in the rat cerebellar cortex of control group showing the outer molecular layer (M) composed of inner basket cells (B). Purkinje cell layer is composed of a single raw of large Purkinje cells (P). Purkinje cell has a large flask shaped body, pale basophilic cytoplasm and vesicular nucleus with prominent nucleolus (arrow). Inner granular cell layer (G) composed of deeply stained granule cells $(\mathrm{g})$, cerebellar glomerulus $(*)$ in between them (H \& E x 400). 


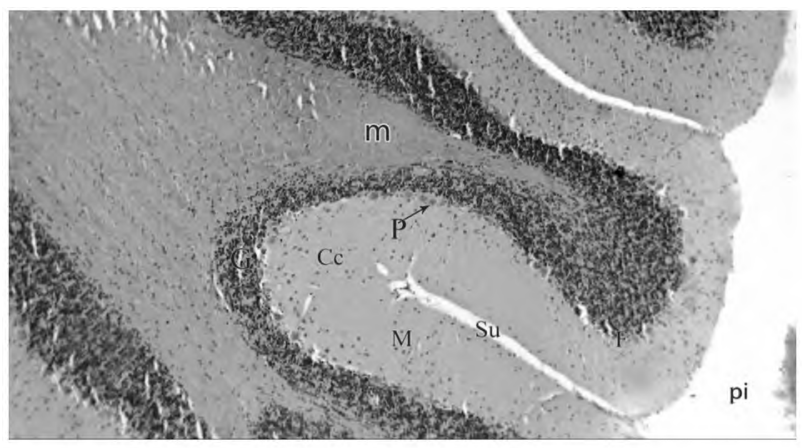

Fig. (3): A photomicrograph of a section in the rat cerebellar cortex of MTX treated group showing the cerebellar cortex with marked thinning in all layers especially granular cell layer, decreased cellularity of molecular cell layer (M). Note, folium $(\mathrm{F})$, cerebellar cortex $(\mathrm{Cc})$, sulcus $(\mathrm{Su})$, pia matter (pi), molecular cell layer (M), Purkinje cell layer (P) and medulla (m) (H \& E x100).

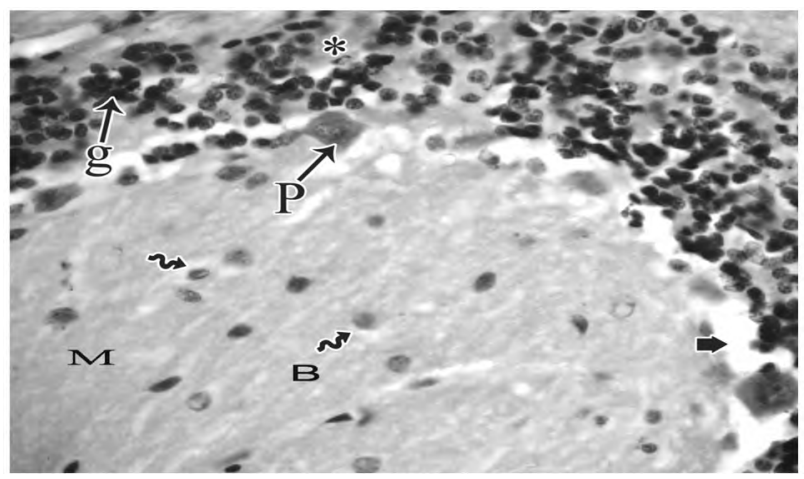

Fig. (4): A photomicrograph of a section in the rat cerebellar cortex of MTX treated group showing the three layers of cerebellar cortex, Purkinje cell (P) is irregular and shrunken with homogenized darkly stained cytoplasm and ill-defined nuclei (arrow), vacuolated spaces between cells (thick arrow). Granular cells (g) are decreased in number, shrunken and with deeply stained nuclei (g). In some areas, they are clumped (arrow) with multiple cerebellar glomeruli (*). Molecular layer (M) shows marked perineural spaces around shrunken basket cells (B) (curved arrow) (H \& E x400).

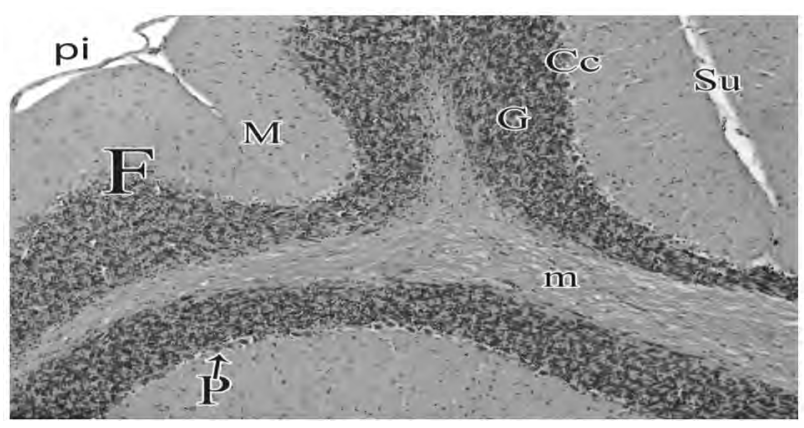

Fig. (5): A photomicrograph of a section in the rat cerebellar cortex of MTX and VC treated group showing increased thickness of all layers especially granular cell layer (G),molecular layer shows normal cellularity (M), Note; folium $(\mathrm{F})$, sulcus $(\mathrm{Su})$, cerebellar cortex $(\mathrm{Cc})$, molecular cell layer (M), Purkinje cell layer $(\mathrm{P})$, pia matter (pi) and medulla (m) $(\mathrm{H} \& \mathrm{E} \times 100)$.

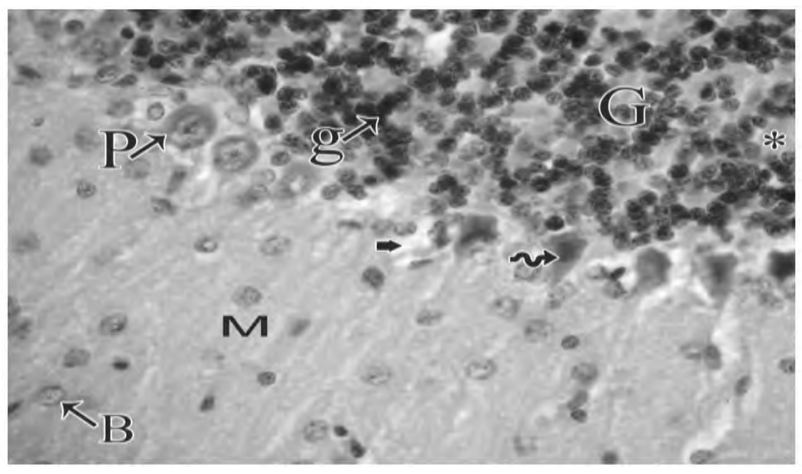

Fig. (6): A photomicrograph of a section in the rat cerebellar cortex of MTX and VC treated group showing basket cells with normal size and more abundant (B) with no perineural spaces around them. Purkinje cells (P) appear within normal size, shape and arrangement, but other cells appear with homogenous cytoplasm and ill-defined nucle (curved arrow), less noted vacuolated areas (thick arrow), granule cells (g) are more crowded with less noted cerebellar glomerulus $(*)$ in between them (H \& E x 400).

\section{Discussion}

The cerebellum is an important organ for motor function, cognition and emotion [4]. The cerebellar cortex has become the focus of intense research, because it is presumed to be responsible for planning movement and adapting to special conditions; it is involved in storing memories over time-periods [20].

MTX is a cytotoxic agent used in an adjuvant chemotherapy cocktail [21]. It is a folic acid antagonist used in non-neoplastic disease like RA and psoriasis [22]. Good results of MTX direct attention on its post therapeutic effects; chemotherapy has a significant toxicity on the nervous system [23] Several hypotheses have been suggested the oxidative stress on the central nervous system [24]. It results from misbalance between ROS generation and antioxidants defenses [25].

$\mathrm{VC}$ is a water-soluble vitamin and natural antioxidant that prevents the oxidative damage in body organs [26]. It is a good scavenger for radicals that destroy membrane lipid and protect against cytotoxicity [27]

The present study specimens treated with MTX showed marked thinning of cerebellar cortex layers, distortion of normal architecture. Purkinje cells appeared irregular shrunken, lost its pyriform shape, dark homogenous cytoplasm and faint nuclei, vacuolated areas appeared around P cells. Granule cells appeared shrunken with deep stained nuclei with multiple cerebellar glomeruli in between them. These results were in acceptance with [22] who showed in methotrexate treated rats that Purkinje 
cells were shrunken in size, lost their specific shaped appearance, some of them were squamous. Pigs were treated with MTX according to [19] showed that Purkinje cells were shrunken and lost flask shape and surrounded with multiple spaces.

In the present study, methotrexate and vitamin $\mathrm{C}$ treated group light microscopic examination showed slight restoration of normal architecture, thickness of cerebellar cortex layers, where Purkinje cells appeared with regular flask shape, arranged in a regular raw with pale basophilic cytoplasm and distinct nuclei with less identified spaces in between them. Granule cells were densely packed with clear cytoplasm with less identified cerebellar glomeruli. These result were in acceptance with $[28,29,30]$ who found at light microscopic examination in specimens of cerebellar cortex in rats received vitamin $\mathrm{C}$ with monosodium glutamate, preserved histological structure but few Purkinje cells were small and irregular, few granular cells were shrunken.

VC reacts with superoxide, hydroxyl radicals and oxygen singlet decreasing the cell damage [31] as it is an electron donor and has the power to return in a reduced form [30]. Brain consumes high amount of oxygen, contains high amounts of polyunsaturated fatty acids and low levels of antioxidants enzymes [25], also it produces ROS more than other organs and therefor it is particularly vulnerable to oxidative stress which is prevented by anti-oxidants like VC [28]. VC has the ability to crossblood brain barrier [29], CNS neurons contain one of the highest VC concentrations in tissues [32]. Moreover, brain has the ability to retain it at the expense of other body tissue during states of chronic deficiency [33].

\section{Conclusion:}

Methotrexate is highly toxic to cerebellar cortex, it destructs the cortical cells especially Purkinje cells and granule cells, administration of vitamin $\mathrm{C}$ can decrease its toxicity.

\section{References}

1- ZHANG C., HUA T., ZHU Z. and LUO X.: Age-related changes of structures in cerebellar cortex of cat. J. Biosci., 31 (1): 55-60, 2006.

2- SHASHI A. and KUMAR J.: Histopathological changes in central nervous system of rats following administration of fluoride: ejbps, 4: (6): 339-345, 2017.

3- SAAD EL-DIEN H., EL GAMAL D.A., MUBARAK H.A. and SALEH S.M.: Effect of fluoride on rat cerebellar cortex: Light and electron microscopic studies. The Egyptian Journal of Histology, 33 (2): 245-256, 2010.
4- KANDEEL S., ELHOSARY N.M. and ABO EL-NOOR M.B.: Electric injury-induced Purkinje cell apoptosis in rat cerebellum. Journal of Chemical Neuroanatomy, 81: 87-96, 2017.

5- KONARSKI J.Z., MELNTYRE R.S., GRUPP L.A. and KENNEDY S.H.: Is the cerebellum relevant in the circuitry of neuropsychiatric disorders? J. Psychiatry Neurosci, 30 (3): 178-186, 2005.

6- STANDRING S.: Grey' Anatomy (The anatomical basis of Clinical practice), Chapter 22, cerebellum: 331-349, forty first edition, Elsevier. London, 2015.

7- VOGEL M.: The cerebellum. Am. J. Psychiatry, 162 (7): 1253, 2005.

8- VANDERAH T.W. and GOULD D.J.: Noltes's the human brain Cerebellum, Chapter 20: 495-523.Seventh edition. Elsevier, Towson, Arizona, Michigan, 2016.

9- MTUI E., GRUENER G. and DOCKERY P.: Fitzgerald's ClinincalNeuroanatomy and Neuroscinece, Chapter 25: 243-252. Seventh edition Elsevier, New York, Ireland, 2016.

10- HORNUNG N., ELLINGSEN T., ATTERMNN J., STENGAARD-PEDERSEN K. and POULSEN J.H.: Patients with rheumatoid arthritis treated with methotrexate: Concentrations of steady-state erythrocyte MTX correlation to plasma concentrations and clinical efficacy. The Journalof Rheumatology, 35 (9): 1709-1715, 2008.

11- BROCK S. and JENNINGS H.R.: Fatal acute encephalomyelitis after single dose of intrathecal methotrexate. Pharmacotherapy, 24 (5): 673-676, 2004.

12- DREW K.L., TOIEN O., RIVEARA P.M., SMITH M.A., PERRY G. and RICE M.E.: Role of the antioxidants in hibernation and worming from hibernation. Comp Biochem. Physiol. C Toxicol. Pharmacol., 133 (4): 483-492, 2002.

13- RAI D.K., RAI P.K., RIZVI S.L., WATEAL G. and SHARMA B.: Carbofuran-induced toxicity in rats: Protective role of vitamin C. Exp. Toxiol. Pathol., 61 (6): 531-5, 2009.

14- LINDBLAD M., TVEDEN-NYBROG P. and LYKKESFELDT J.: Regulation of vitamin C homeostasis during deficiency. Nutrients, 5 (8): 2860-2879, 2013.

15- RICE M.E.: Ascorbic regulation and its neuroprotective role in the brain. Trends Neurosci., 23 (5): 209-216, 2000.

16- QIU S., LI L., WEEBER E.J. and MAY J.M.: Ascorbate transport by primary cultured neuronal function and protection against excitotoxicity. J. Neurosci. Res., 85 (5): 1046-56, 2007.

17- EL-BADAWI M.G., FATANI J.A., BAHAKIM H. and ABDALLA M.A.: light and electron microscopic observation on the cerebellum of guinea pigs following low dose methotrexate. Experimental and Molecular Pathology, 53 (3): 211-222, 1990.

18- EL-NEWESHY M.S. and EL-SAYED Y.S.: Influence of vitamin c supplementation on lead-induced histopathological alterations in male rats. Experimental and Toxicologic Pathology, 63 (3): 221-227, 2011.

19- BANCROFT J.D. and GAMBLE M.: Theory and practice of histological techniques, page 179, sixth edition. Elsevier Churchill Livingstone, London, 2007. 
20- ATTWELL P.J., COOKE S.F. and YEO C.H.: Cerebellar Function in consolidation of a motor memory. Neuron, 34 (6): 1011-1020, 2002.

21- SEIGERS R., POURTAU L., SCHAGEN S.B., DAM F.S.A.M. FRITS, et al.: Inhibition of hippocampal proliferation by methotrexate in rats is not potentiated by the presence of a tumor. Brain Research Bulletin, 81 (4): 472476, 2010.

22- VARDI N., PARLAKPINAR H. and ATES B.: Beneficial effects of chlorogenic acid in methotrexate-induced cerebellar Purkinje cell damage in rats. Journal of Chemical Neuroanatomy, 43 (1): 43-47, 2012.

23- RZESKI W., PRUSKIL S., MACKE A., FEELDERHOFFMUESR U., REIHER A.K., HOERSTER F., JANSMA C., JAROSZ B., STEFOVSKAT V., BITTIGAU P. and IKONOMIDEOU C.: Anti-cancer agents are potent neurotoxins in vitro and in vivo; Ann. Neurol., 56 (3): 351360, 2004.

24- MIKETOVA P., KAEMINGK K., HOCKENBERRY M., PASVOGEL M., HUTTER A., KRULL K. and MOORE L.M.K.: Oxidative changes in cerebral spinal fluid phosphatidylcholine during treatment for acute lymphoblastic leukemia. Biol. Res. Nurs., 6 (3): 187-95, 2005.

25- ELSAWY H., AL-OMAIR M.A., SEDKY A. and ALOTAIBI L.: Protective effect of lipoic acid against cypermethrin-induced changes in rat cerebellum. Journal of Chemical Neuroanatomy, 86: 52-57, 2017.

26- NAYANATARA A.K., VINODIDI N.A., AHMED B., RAMASWAMY C.R., SHABARIANTH G. and RAMESH BHAT M.: Role of ascorbic acid in monosodium glutamate mediated effects on testicular weight, sperm morphology and sperm count in rat testis. Journal of Chinese Clinical Medicine, 3 (1): 1-5, 2008.

27- RAGAB E.E.: The possible protective effect of vitamin
$\mathrm{C}$ on monosodium glutamate induced renal toxicity in male albino rats. The Egyptian Journal of Histology, 41 (4): 386-397, 2018.

28- HASHEM H.E., SAFWAT M.D. EL-DIN and ALGAIDI S.: Theeffectof monosodium glutamate on the cerebellar cortex of male albino rats and the protective role of Vitamin C (histological and immunohisochemical study. J. Mol. Histo., 43 (2): 179-86, 2012.

29- AIDAROS A.E., IBRAHIM A.A., MOHAMMED H.O. and HASSAN N.H.: Effects of monosodium glutamate on the cerebellar cortex of male albino rat and protective effective role of vitamin C. The Egyptian Journal of Histology, 25 (2): 251-260, 2019.

30- MEKKAWY A.M., AHMED Y.H., KHALAF A.A. and EL-SAKHAWY M.A.: Ameliorative effect of nigella sativa and vitamin $\mathrm{C}$ on the thyroid gland and cerebellum of adult male albino rats exposed to monosodium glutamate (histological, immunohistochemical and biochemical studies). Tissue and Cell, 66: 101-391, 2020.

31- ALI M.H.M., NASR EL-DIN W.A. and ANTER S.: Possible ameliorating effect of vitamin $\mathrm{C}$ on cerebellar toxicity induced by gibberellic acid during late pregnancy and early postnatal periods in albino rats. Eur. J. Anat., 22 (4): 354-354, 2018.

32- DORTAJ H., YADEGARI M., ABAD M.H.S., SCRCHESHMEH A.A. and ANVARI M.: Research paper: Stereological method for assessing the effect of vitamin $\mathrm{C}$ administration on the reduction of acrylamide-induced neurotoxicity. Basic and Clinical Neuroscience, 9 (1): 28-34, 2018.

33- COVEÑAS R., GONZÁLEZ-FUENTES J., RIVASINFANTE E., LAGARTOS-DONATE M.J., MANGAS A.M., GEFFARD M., et al.: Developmental study of vitamin $C$ distribution in children's brainstems by immunohistochemistry. Annals of Anatomy, 201: 65-78, 2015. 


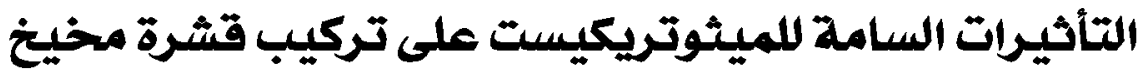

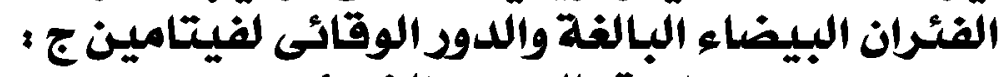 دراسية بالمجهر الضوئى}

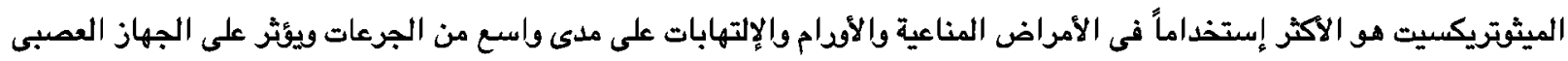

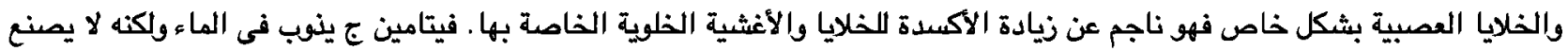

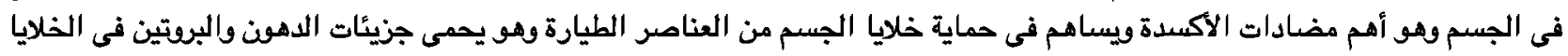

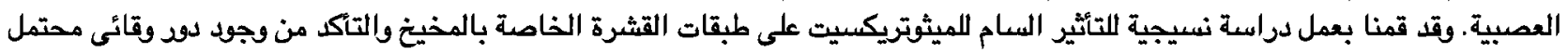

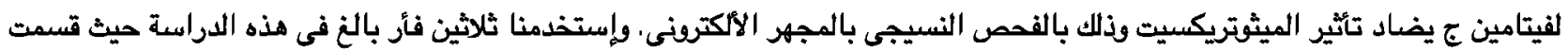

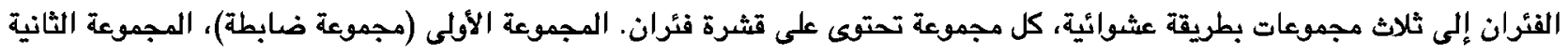

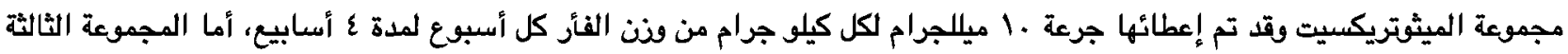

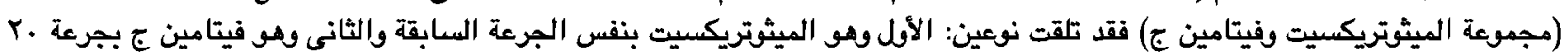

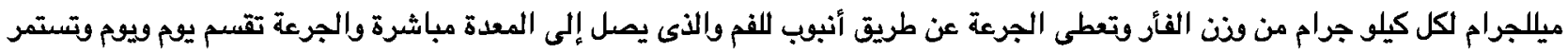

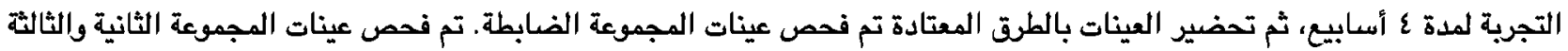

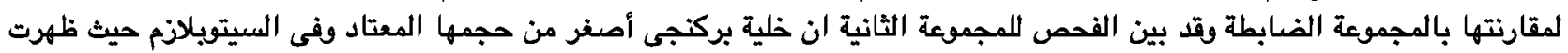

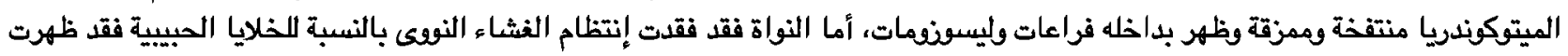

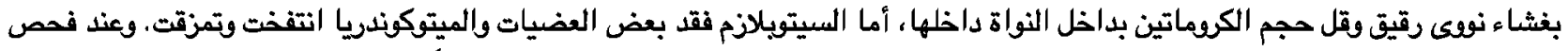
المجموعة الثالثة وجد إستعادة خلية بركنجى والخلايا الحبيبية الشكل الطبيعى والتركيب الطبي الطبيعى تقريباً. 